\title{
ANALISIS KEMAMPUAN TECHNOLOGICAL KNOWLEDGE CALON GURU SEKOLAH DASAR
}

\author{
Hesti Fitriyana, Punaji Setyosari, Saida Ulfa \\ Jurusan Teknologi Pendidikan, Fakultas Ilmu Pendidikan, Universitas Negeri Malang \\ Jalan Semarang 5 Malang $651450341-574700$ \\ hesti.fitriyana@gmail.com
}

Article History

Received: 11 Januari 2021, Accepted: 16 Maret 2021, Published: 20 November 2021

\begin{abstract}
Abstrak
Guru yang kompeten dan professional merupakan hal penting yang harus ada demi terwujudnya pendidikan yang berkualitas. Technological Knowledge (TK) merupakan bagian dari kerangka TPACK merupakan pengetahuan guru tentang teknologi yang mampu menunjang pembelajaran. Penelitian ini bertujuan untuk mengetahui gambaran kemampuan TK calon guru sekolah dasar mahasiswa PGSD FIP UM. Penelitian ini menggunakan metode penelitian kuantitatif deskriptif karena mendeskripsikan kemampuan TK calon guru menggunakan data numerik yang dianalisis. Dari penelitian yang sudah dilakukan dapat diketahui bahwa pengetahuan calon guru tentang macam software dan teknologi dikategorikan sangat baik, kemampuan mengajar peserta didik menggunakan software berbasis web dikategorikan sangat baik, kemampuan menggunakan software dikategorikan baik, kemampuan menggunakan hardware dikategorikan baik. Berdasarkan hasil penelitian dapat disimpulkan bahwa kemampuan TK calon guru sekolah dasar PGSD FIP UM termasuk dalam kategori sangat baik.
\end{abstract}

Keyword: TPACK; Kemampuan Technological Knowledge; Calon guru Sekolah Dasar

\begin{abstract}
Competent and professional teachers are important things that must exist for the realization of quality education. Technological Knowledge (TK) is part of the TPACK framework, which is the knowledge of teachers about technology that can support learning. This study aims to determine the ability of kindergarten elementary school teacher candidates for PGSD FIP UM students. This research uses the descriptive quantitative research method because it describes the ability of kindergarten teacher candidates using the analyzed numerical data. From the research that has been done, it can be seen that the knowledge of prospective teachers about types of software and technology is categorized as very good, the ability to teach students using web-based software is categorized as very good, the ability to use the software is categorized as good, the ability to use hardware is categorized as good. Based on the results of the study, it can be concluded that the ability of prospective elementary school teachers of PGSD FIP UM Kindergarten is included in the very good category.
\end{abstract}

Keyword: TPACK; Capability of Technological Knowledge; Prospective Elementary School teachers 


\section{PENDAHULUAN}

Pendidikan tidak pernah lepas dari perkembangan teknologi yang bertumbuh pesat hingga keseluruh sektor kehidupan manusia. Layaknya benda dinamis yang terus menerus bergerak, dunia pendidikan terus bergerak dan mengalami penyesuaian kondisi di setiap zaman. Dewasa ini kemajuan teknologi yang semakin masif dan terbuka lebarnya akses informasi memberikan peluang dan pengaruh yang amat signifikan bagi dunia pendidikan. Metode dan model pembelajaran konvensional kini mulai berubah menuju kearah pembelajaran digital yang lebih mutakhir seperti pembelajaran daring (dalam jaringan) dan munculnya kelas-kelas maya. Perkembangan dunia yang melaju pesat tentunya juga layak diimbangi dengan praktik pendidikan yang selaras dengan tuntutan perubahan tersebut. Selain itu untuk terus meningkatkan kualitas pembelajaran dan pembaharuan mutu pendidikan, seorang pendidik juga wajib mengikuti perkembangan ilmu pengetahuan dan teknologi sebagai media penyampaian materi serta bagaimana cara mengajar yang efektif namun juga efisien (Mishra \& Koehler, 2006).

Pada era abad 21 saat ini kemajuan teknologi mengalami pertumbuhan yang begitu cepatnya seiring dengan Revolusi Industri 4.0, sehingga setiap negara membutuhkan sumber daya manusia (SDM) yang memegang tiga pilar penting. Dalam World Economic Forum 2015, ketiga pilar tersebut terdiri dari penguasaan literasi, kompetensi dan karakter. Pada tahun 2009 laporan berjudul "Learning for the 21st Century" mempublikasikan "Framework for 21st Century Learning" yang menerangkan tentang empat kompetensi atau keterampilan yang wajib dimiliki oleh anak didik, yang meliputi (1) mata pelajaran inti dan tema abad ke-21, (2) pembelajaran dan keterampilan inovatif, (3) keterampilan informasi, media dan teknologi dan (4) keterampilan hidup dan karier (Marzano \& Heflebower, 2012). Sedangkan menurut Triling dan Fadel (2009) antara lain adalah (1) keterampilan hidup dan karier, (2) keterampilan belajar dan inovasi, dan (3) keterampilan media informasi dan teknologi. Kompetensi tersebut merupakan kerangka pembelajaran di abad 21 yang dijalankan sebagai bentuk upaya guna menyelaraskan praktik pendidikan. Berdasarkan kedua pernyataan tersebut dapat diartikan bahwa penguasaan teknologi menjadi salah satu kompetensi yang wajib dipunyai peserta didik.

Perubahan zaman yang melesat cepat mengharuskan para calon guru lebih tanggap meresponnya. Guru diharuskan memiliki banyak kemampuan agar mampu menciptakan pembelajaran efektif serta efisien (Candra, 2019). Pada strata pendidikan Sekolah Dasar (SD), merupakan awal peletakan pondasi kecerdasan intelektual, spiritual, dan emosional. Pada setiap aspek kecerdasan tersebut keterampilan pendidik harus bisa mengimbangi perkembangan era modern (Ibda, 2018). Untuk menguatkan literasi pada ranah pendidikan, sejak tahun 2016 Kementrian Pendidikan dan Kebudayaan Republik Indonesia telah melaksanakan kegiatan Gerakan Literasi Nasional (GLN). Program dari kementrian ini ialah bentuk pengimplementasian dari Permendikbud Nomor 23 Tahun 2015 tentang Penumbuhan Budi Pekerti. Fokus utama dari program ini terbagi menjadi enam aspek, yakni literasi membaca serta menulis, sains, numerasi, keuangan, digital, dan budaya $\&$ kewargaan.

Keberadaan guru yang terampil dan professional ialah hal penting yang wajib ada demi terwujudnya pendidikan berkualitas. Seorang guru profesional wajib menguasai kompetensi TPACK yang layak karena kompetensi ini berada dalam ranah empat kompetensi utama seorang guru. Sebagaimana yang tertera dalam Undang-Undang Republik Indonesia No. 14 Tahun 2005 Tentang Guru dan Dosen, kompetensi tersebut yakni kompetensi pedagogik, kompetensi kepribadian, kompetensi sosial dan kompetensi professional. TPACK pertamakali dicetuskan oleh Shulman (1987) dan kemudian disempurnakan oleh Koehler dan Mishra (2008) yang merumuskan suatu kerangkan dimana pengetahuan seorang pendidik di era teknologi yang berkembang haruslah mempunyai tiga unsur yang saling bersangkutan yaitu Content Knowledge (CK), Pedagogical Knowledge (PK), dan Technological Knowledge (TK). Dari ketiga unsur tersebut terbentuk suatu konsep baru dari hasil penambahan teknologi yaitu Technological Pedagogical Content Knowledge (TPACK). 


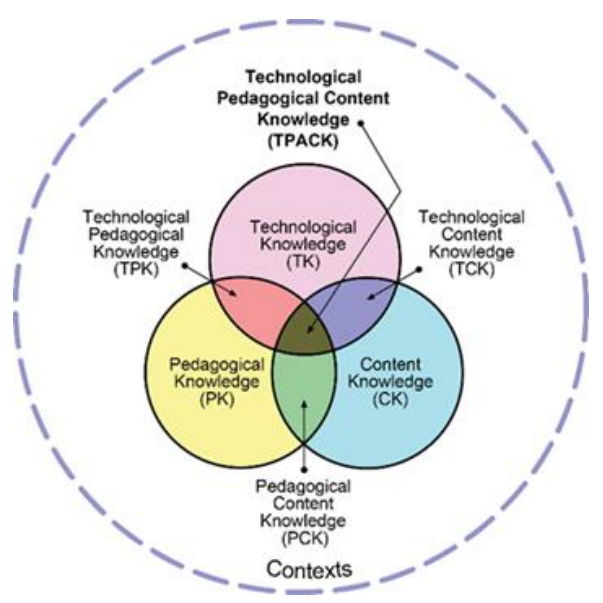

\section{Gambar 1. Kerangka dan Komponen TPACK (Koehler dan Mishra, 2008)}

Technological Knowledge merupakan ilmu yang wajib dimiliki pendidik mengenai teknologi yang bisa mendukung suatu pembelajaran. TK mencakup pemahaman pendidik dalam pemanfaatan unsur-unsur komputer, serta peralatan pendukung dan teknologi lainnya yang berkaitan dengan pendidikan dan pembelajaran. Selain dituntut mempunyai pengetahuan berkaitan dengan teknologi, pengajar diharuskan mempunyai kecakapan untuk mengadaptasi dan mempelajari teknologi baru. Kemampuan inilah yang perlu dikuasai pendidik mengingat kemajuan dan perubahan teknologi selalu berkembang (Rosyid, 2016).

Teknologi bersifat fleksibel yang mana bisa menjadi solusi untuk mengembangkan pembelajaran agar lebih bermakna (Fuada, 2020). Teknologi yang kini berkembang dapat dipakai sebagai alat kognitif dalam proses pembelajaran (Listiawan, 2015). Dengan hadirnya pemanfaatan teknologi dalam proses belajar mengajar bisa memberikan banyak manfaat seperti menambah motivasi belajar bagi siswa. Teknologi dapat mengilustrasikan materi abstrak dan bisa menunjang pembelajaran anak didik.

Program Studi Pendidikan Guru Sekolah Dasar Fakultas Ilmu Pendidikan Universitas Negeri Malang adalah salah satu Lembaga Pendidikan Tenaga Kependidikan (LPTK) yang melahirkan lulusan calon guru sekolah dasar. Sebagai pencetak calon guru sekolah dasar lulusan PGSD diharapkan memiliki keterampilan untuk mengembangkan ilmu kependidikan selaras dengan perkembangan IPTEK.

Penelitian ini bertujuan untuk memperoleh informasi dan mendeskripsikan pengetahuan mengenai teknologi calon guru sekolah dasar. Berbeda dengan penelitian-penelitian sebelumnya yang telah dilaksanakan tentang TPACK kepada calon guru sekolah dasar, kebanyakan hanya mengungkap ataupun mengukur kemampuan calon guru pada domain PK ataupun CK saja. Penelitian kali ini difokuskan hanya pada aspek pengetahuan maupun kemampuan calon guru dalam menggunakan teknologi saja. Hal ini menjadi bekal calon guru guna menghadapi tantangan kemajuan global. Berdasarkan hal inilah penulis tertarik untuk meneliti tentang kemampuan TK mahasiswa calon guru sekolah dasar di FIP UM angkatan 2017.

\section{METODE}

Metode yang digunakan ialah pendekatan kuantitatif dengan jenis penelitian analisis deskriptif. Desain deskriptif dipilih karena selaras dengan tujuan penelitian, yakni untuk mendeskripsikan kemampuan TK mahasiswa calon guru sekolah dasar. Penelitian deskriptif bertujuan untuk memaparkan fenomenafenomena yang ada, baik fenomena yang bersifat natural ataupun buatan manusia. Penelitian yang bertujuan untuk mengungkap suatu fenomena ataupun karakteristik individual, situasi maupun 
kelompok tertentu secara akurat. (Sukmadinata, 2011). Berdasarkan pendapat Arikunto (2006), bahwa pendekatan ini menggunakan angka, mulai dari pengumpulan data, penafsiran dalam data, serta penyajian data. Pendekatan kuantitatif bermaksud untuk mengungkap fenomena menggunakan datadata numerik, kemudian data tersebut akan dianalisis.

Penelitian ini diselenggarakan pada bulan November 2020 tahun ajaran 2020/2021. Populasi dan sampel yaitu mahasiswa Program Studi PGSD FIP UM angkatan 2017. Sampel diambil memakai teknik sampling yaitu simple random sampling, kemudian memilih mahasiswa calon guru Sekolah Dasar secara acak pada mahasiswa Program Studi PGSD FIP UM angkatan 2017 sejumlah 60 mahasiswa. Alat pengumpulan data dalam penelitian ini menggunakan kuisioner. Kuisioner atau sering juga disebut angket ialah sekumpulan daftar pertanyaan/pernyataan yang wajib diisi oleh subjek penelitian (responden) sehubungan dengan topik penelitian yang akan diteliti. Kuisioner dikembangkan berdasarkan indikator yang diuraikan pada Tabel 1.

Tabel 1. Kisi-kisi Instrumen

\begin{tabular}{|c|c|c|c|c|}
\hline Variabel & Aspek & Indikator & Butir & Jumlah \\
\hline \multirow{4}{*}{$\begin{array}{l}\text { Technological } \\
\text { Knowledge }\end{array}$} & $\begin{array}{l}\text { 1. Pengetahuan } \\
\text { Teknologi }\end{array}$ & $\begin{array}{l}\text { Pengetahuan tentang } \\
\text { macam software dan } \\
\text { teknologi }\end{array}$ & $\begin{array}{l}1,2,3 \\
4,5,6 \\
7,8,9 \\
\text { dan } 10\end{array}$ & 10 \\
\hline & \multirow{3}{*}{$\begin{array}{l}\text { Penggunaan } \\
\text { Teknologi }\end{array}$} & $\begin{array}{ll}\text { a. } & \text { Kemampuan } \\
\text { mengajar peserta } \\
\text { didik menggunakan } \\
\text { platform berbasis web }\end{array}$ & $\begin{array}{l}11, \text { dan } \\
12\end{array}$ & 2 \\
\hline & & 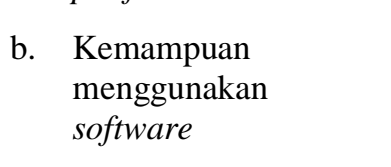 & $\begin{array}{l}13,14 \\
15,16 \\
17,18 \\
\text { dan } 20\end{array}$ & 6 \\
\hline & & $\begin{array}{ll}\text { c. } & \text { Kemampuan } \\
\text { menggunakan } \\
\text { hardware }\end{array}$ & 19 & 2 \\
\hline
\end{tabular}

Kemudian indikator tersebut dijabarkan kedalam butir-butir pernyataan sebanyak 20 butir pernyataan. Selanjutnya dilakukan uji validitas menggunakan SPSS v.20 dengan mengujicobakan instrumen kepada 30 responden. Pada jumlah responden $n=30$ dengan interval kepercayaan $95 \%$ maka diperoleh $\quad 0,361$. Uji validitas menggunakan rumus korelasi sederhana yaitu melalui korelasi product moment. Dari hasil kalkulasi butir 1 sampai dengan butir 20 menujukkan bahwa $r$ hitung lebih besar dari $r$ tabel 0,361 sehingga instrumen dinyatakan valid. Kemudian dilakukan uji reliabilitas instrumen menggunakan SPSS v.20 dengan mengkalkulasi besarnya nilai Cronbach's Alpha dari variabel yang diuji. Dari hasil uji reliabilitas didapatkan hasil nilai Cronbach's Alpha lebih besar dari 0.600 yaitu sebesar 0,855 yang berarti interpretasi besarnya nilai $\mathrm{r}$ adalah tinggi maka instrumen dinyatakan reliabel. Kuisioner kemudian diukur menggunakan skala likert. Melalui skala likert, maka variabel yang akan diukur diuraikan menjadi indikator variabel. Dalam skala likert, terdapat 5 (lima) pilihan alternatif jawaban. Lima skala tersebut diantaranya Sangat Setuju $(S S)=5$, Setuju $(S)=4$, Kurang Setuju $(\mathrm{KS})=3$, Tidak Setuju $(\mathrm{TS})=2$, dan Sangat Tidak Setuju $($ STS $)=1$.

\section{HASIL}

Dalam penelitian ini kemampuan TK calon guru sekolah dasar hanya dibatasi pada 2 aspek, yakni aspek pengetahuan teknologi dan aspek penggunaan teknologi. Pada aspek pengetahuan teknologi hanya dibatasi pada indikator pengetahuan tentang macam software dan teknologi saja, sedangkan dalam aspek penggunaan terdapat tiga indikator yang diukur yakni kemampuan mengajar peserta didik 
menggunakan platform berbasis web, kemampuan menggunakan software, dan kemampuan menggunakan hardware. Gambaran distribusi frekuensi kemampuan TK pada aspek pengetahuan teknologi disajikan pada Tabel 2.

Tabel 2. Distribusi Kecenderungan Skor Rerata Kemampuan Technological Knowledge ditinjau dari Aspek Pengetahuan Teknologi berdasarkan Indikator Pengetahuan tentang Software dan Teknologi

\begin{tabular}{lllcc}
\hline No & Rentang & Kategori & Frekuensi & Percent (\%) \\
\hline 1. & $\mathrm{X}>40$ & Sangat Baik (SB) & 46 & 76,7 \\
2. & $33,3<\mathrm{X} \leq 40$ & Baik (B) & 14 & 23,3 \\
3. & $26,7<\mathrm{X} \leq 33,3$ & Cukup (C) & 0 & 0 \\
4. & $20<\mathrm{X} \leq 26,7$ & Kurang (K) & 0 & 0 \\
5. & $\mathrm{X} \leq 20$ & Sangat Kurang (SK) & 0 & 0 \\
\hline & & Jumlah & 60 & 100 \\
\hline
\end{tabular}

Berdasarkan Tabel 2. dapat diketahui bahwa kemampuan TK ditinjau dari aspek pengetahuan teknologi berdasarkan indikator pengetahuan tentang software dan teknologi, dari 60 responden sebanyak 46 responden $(76,7 \%)$ dikategorikan sangat baik (SB), 14 responden $(23,3 \%)$ dikategorikan baik (B) dan tidak ada responden yang dikategorikan dalam kategori cukup (C), kurang (K) dan sangat kurang (SK). Gambaran distribusi frekuensi kemampuan TK pada aspek penggunaan teknologi disajikan pada Tabel 3, Tabel 4, dan Tabel 5

Tabel 3. Distribusi Kecenderungan Skor Rerata Kemampuan Technological Knowledge Aspek Penggunaan Teknologi ditinjau dari Kemampuan Menggunakan Software

\begin{tabular}{lllcc}
\hline No & Rentang & Kategori & Frekuensi & Percent (\%) \\
\hline 1. & $\mathrm{X}>7,95$ & Sangat Baik (SB) & 57 & 95.0 \\
2. & $6,65<\mathrm{X} \leq 7,95$ & Baik (B) & 3 & 5.0 \\
3. & $5,35<\mathrm{X} \leq 6,65$ & Cukup (C) & 0 & 0 \\
4. & $34,05<\mathrm{X} \leq 5,35$ & Kurang (K) & 0 & 0 \\
5. & $\mathrm{X} \leq 4,05$ & Sangat Kurang (SK) & 0 & 0 \\
\hline & & Jumlah & 60 & 100 \\
\hline
\end{tabular}

Berdasarkan Tabel 3. dapat diketahui bahwa kemampuan TK ditinjau dari aspek penggunaan teknologi berdasarkan indikator kemampuan mengajar peserta didik menggunakan platform berbasis web, dari 60 responden sebanyak 57 responden (95\%) dikategorikan sangat baik (SB), 3 responden (5\%) dikategorikan baik (B) dan tidak ada responden yang dikategorikan dalam kategori cukup (C), kurang (K) dan sangat kurang (SK).

Tabel 4. Distribusi Kecenderungan Skor Rerata Kemampuan Technological Knowledge Aspek Penggunaan Teknologi ditinjau dari Kemampuan Menggunakan Software

\begin{tabular}{lllcc}
\hline No & Rentang & Kategori & Frekuensi & Percent (\%) \\
\hline 1. & $\mathrm{X}>24$ & Sangat Baik (SB) & 26 & 43.3 \\
2. & $20<\mathrm{X} \leq 24$ & Baik (B) & 26 & 43.3 \\
3. & $16<\mathrm{X} \leq 20$ & Cukup (C) & 8 & 13.4 \\
4. & $12<\mathrm{X} \leq 16$ & Kurang (K) & 0 & 0 \\
5. & $\mathrm{X} \leq 12$ & Sangat Kurang (SK) & 60 & 0 \\
\hline
\end{tabular}

Berdasarkan Tabel 4. dapat diketahui bahwa kemampuan TK ditinjau dari aspek penggunaan teknologi berdasarkan indikator kemampuan menggunakan software, dari 60 responden sebanyak 26 responden $(43,3 \%)$ dikategorikan sangat baik (SB), 26 responden $(43,3 \%)$ dikategorikan baik (B), 8 responden $(13,4)$ dikategorikan cukup $(\mathrm{C})$, dan tidak ada responden yang dikategorikan dalam kategori kurang (K) dan sangat kurang (SK). 
Tabel 5. Distribusi Kecenderungan Skor Rerata Kemampuan Technological Knowledge Aspek Penggunaan Teknologi ditinjau dari Kemampuan Menggunakan Hardware

\begin{tabular}{lllcc}
\hline No & Rentang & Kategori & Frekuensi & Percent (\%) \\
\hline 1. & $\mathrm{X}>7,95$ & Sangat Baik (SB) & 51 & 95.0 \\
2. & $6,65<\mathrm{X} \leq 7,95$ & Baik (B) & 7 & 5.0 \\
3. & $5,35<\mathrm{X} \leq 6,65$ & Cukup (C) & 2 & 0 \\
4. & $34,05<\mathrm{X} \leq 5,35$ & Kurang (K) & 0 & 0 \\
5. & $\mathrm{X} \leq 4,05$ & Sangat Kurang (SK) & 0 & 0 \\
\hline & & Jumlah & 60 & 100 \\
\hline
\end{tabular}

Berdasarkan Tabel 5. dapat diketahui bahwa kemampuan TK ditinjau dari aspek penggunaan teknologi berdasarkan indikator kemampuan menggunakan hardware, dari 60 responden sebanyak 21 responden $(35.0 \%)$ dikategorikan sangat baik (SB), 37 responden (61.7\%) dikategorikan baik (B), 2 responden $(3,3)$ dikategorikan cukup $(\mathrm{C})$, dan tidak ada responden dikategorikan dalam kategori kurang baik (K) dan sangat kurang (SK).

Dari uraian tabel diatas dapat diketahui bahwa kemampuan TK ditinjau dari aspek pengetahuan teknologi berdasarkan indikator pengetahuan tentang software dan teknologi pada kategori sangat baik dengan persentase sebesar $85,64 \%$. Kemampuan TK ditinjau dari aspek penggunaan teknologi berdasarkan indikator kemampuan mengajar peserta didik menggunakan platform berbasis pada kategori sangat baik dengan persentase sebesar 88.8\%. Kemampuan TK ditinjau dari aspek penggunaan teknologi berdasarkan indikator kemampuan menggunakan software pada kategori baik dengan persentase sebesar $80 \%$. Kemampuan TK ditinjau dari aspek penggunaan teknologi berdasarkan indikator kemampuan menggunakan hardware pada kategori baik dengan persentase sebesar $83,3 \%$.

\section{PEMBAHASAN}

Pada tahun-tahun sebelumnya, gagasan TPACK telah menyebar dan diadopsi oleh negara-negara di dunia sebagai upaya meningkatkan kemampuan pengajar dalam mengintegrasikan informasi teknologi komunikasi (ICT) (Chai, Koh dan Tsai, 2013). TPACK adalah pengetahuan pengajar mengenai bagaimana memfasilitasi pembelajaran bagi anak didik dari suatu konten tertentu melalui pendekatan pedagogik dan teknologi (Cox \& Graham, 2009). Pada awal perkembangan TPACK, guru hanya diwajibkan menguasai aspek konten pelajaran dan aspek pedagogi saja, namun di era pembelajaran digital seperti sekarang guru dituntut harus mengikuti melesatnya perkembangan teknologi. Oleh sebab itu, pengintegrasian antara aspek materi, pedagogi dan teknologi sangat penting. Di negaranegara maju, integrasi teknologi, pedagogi dan konten dalam bentuk perangkat pembelajaran bertema TPACK menjadi solusi kreatif yang dikembangkan dalam konteks pembelajaran. Kerangka kerja tesebut merupakan bentuk kesatuan antara teknologi, materi dan pedagogi yang saling berinteraksi untuk menciptakan pembelajaran bertema TIK. Karenanya, kemampuan itu amat perlu diperkuat sebagai pondasi utama pengajar dalam mempersiapkan diri sebelum menghadapi siswa di kelas.

Teknologi memainkan peranan penting dalam kehidupan seorang pendidik maupun seseorang pelajar. Calon pengajar yang menguasai kompetensi tersebut mampu mengintegrasikan kecakapan teknologi dalam sistem pembelajaran sesuai dengan konten pelajaran dan strategi pembelajaran yang tepat berdasarkan karakteristik siswa. Menurut Fuada (2020), tiga indikator yang kiranya dapat merepresentasikan tenaga pendidik profesional diantaranya memiliki kemampuan dalam mengadopsi berbagai informasi, kemampuan melakukan komunikasi, serta kemampuan menguasai teknologi pendidikan. Pengajar profesional dapat menguasai materi pembelajaran dan mengkolaborasikannya dengan teknologi terbaru.

Teknologi mendukung pembelajaran anak didik dalam mempersiapkan karir mereka di kemudian hari dimana teknologi informasi telah menjadi suatu gaya hidup (Setyosari, 2019). Teknologi dan 
pendekatan baru yang menyatukan dunia fisik, digital, dan biologi secara mendasar telah memperbarui pola hidup dan interaksi manusia (Tjandrawinata, 2016). TPACK muncul beriringan dengan perkembangan dan kemajuan teknologi dibidang pendidikan dan pembelajaran (Surahman, 2020). TPACK dianggap sebagai kerangka kerja yang mampu memberikan pandangan baru bagi pengajar dalam menangani masalah terkait dengan pengintegrasian teknologi dalam proses belajar mengajar di kelas (Hewitt, 2008). Jordan \& Dinh (2012) menerangkan bahwa tantangan guru dimasa kini ialah mengembangkan keterampilan berteknologi untuk mempelajari bagaimana mengintegrasikan teknologi baru kedalam proses pembelajaran.

Technological Knowledge yang dimanfatkan dalam pembelajaran untuk mengintegrasikan CK, PK, dan PCK menjadi satu kesatuan yang utuh akan menciptakan suasana pembelajaran yang lebih menarik, efektif serta efisien (Sintawati, 2019). Menurut Nasution (2018) terdapat banyak manfaat bisa diperoleh saat memanfaatkan teknologi dalam pembelajaran diantaranya 1) bagi pebelajar meningkatkan perhatian, konsentrasi, motivasi, dan kemandirian, 2) bagi pengajar dapat mereduksi waktu dalam penyampaian materi, membuat pengalaman belajar belajar siswa yang lebih menyenangkan, merancang materi menjadi lebih menarik, dan memicu pengajar untuk mengembangkan pengetahuan dan kemampuannya tentang komputer. Alavi (2003) menguraikan beberapa tujuan penggunaan teknologi dalam pembelajaran yakni meningkatkan kualitas pembelajaran, kepuasan peserta didik, penghasilan, dan kualitas pelayanan.

Hidayati, Setyosari, dan Soepriyanto (2019) dalam penelitiannya, mengungkapkan aspek yang paling rendah dalam tujuh domain TPACK guru soshum SMA/SMK sederajat di Kota Malang ada pada domain TCK. Hasil penelitian Dhawati (2017) mengungkap kemampuan TK calon guru Biologi FKIP UMS dalam menyusun RPP kurikulum 2013 tergolong dalam kategori baik. Hal tersebut didukung juga oleh penelitian Lestari (2016) tingkat kemampuan penguasaan TK sering kali tidak sebanding dengan lamanya pengalaman mengajar dari seorang guru. Selaras dengan penelitian Arbianto (2019) tentang Kesiapan Technological Knowledge (TK) calon guru bidang teknik UM bahwa hasil analisis menunjukkan persentase tertinggi yaitu pada kategori baik. Sehubungan dengan kemajuan teknologi tersebut maka perlu adanya penguatan terhadap kemampuan teknologi calon guru Sekolah Dasar sebagai bekal untuk mengembangkan profesionalitas dan kesiapan dalam menghadapi tantangan pembelajaran di abad 21.

Berdasarkan hasil kuisioner yang dianalisis dari aspek pengetahuan teknologi mahasiswa calon guru PGSD FIP UM tergolong dalam kategori sangat baik. Sebagian besar mahasiswa sudah mengetahui berbagai macam platform media social (seperti; Blog, Facebook, dan Youtube), platform LMS (Learning Management System) (seperti; Google Classroom, Edmodo, Moodle dan Dokeos), software conference seperti; Skype, Google Meet, dan Zoom, software dasar seperti aplikasi office (seperti; Word, Excel, dan Powerpoint), pembuat kuis pembelajaran (seperti; Kahoot dan Quizizz), pengolah gambar (seperti; Adobe Photoshop, CorelDraw dan Adobe Illustrator), pengolah video (Movie Maker, Power Director, dan Adobe Premiere), pembuat media pembelajaran (seperti; Adobe Flash, Autoplay, dan Lectora), pembuat animasi 2D dan 3D (seperti; 3dsMax dan Blender) dan teknologi seperti Augmented Reality (AR) dan Virtual Reality (VR). Berdasarkan hasil analisis data di atas, diketahui rerata terendah terdapat pada item pernyataan nomor 8 dengan perolehan skor rerata 3,53, pernyataan "Saya mengetahui aplikasi untuk membuat media pembelajaran seperti; Adobe Flash, Autoplay, dan Lectora" dan diketahui rerata tertinggi terdapat pada item penyataan nomor 1 dengan perolehan skor rerata 4,91 "Saya mengetahui platform media social seperti; Blog, Facebook, dan Youtube".

Pada aspek penggunaan teknologi diketahui bahwa kemampuan penggunaan teknologi mahasiswa calon guru Sekolah Dasar ditinjau dari indikator kemampuan mengajar menggunakan platform berbasis web dikategorikan baik. Mahasiswa calon guru sudah mampu mengajar menggunakan 
platform berbasis web menggunakan media social (seperti; Blog, Facebook, dan Youtube), platform LSM (Learning Management System) (seperti; Google Classroom, Edmodo, Moodle, dan Dokeos), dan software conference (seperti; Skype, Google Meet, Zoom). Diketahui kemampuan menggunakan software office (seperti; Word, Excel, dan Powerpoint), pembuat kuis pembelajaran (seperti; Kahoot dan Quizizz), pengolah gambar (seperti; Adobe Photoshop, CorelDraw dan Adobe Illustrator), pengolah video (Movie Maker, Power Director, dan Adobe Premiere), pembuat media pembelajaran (seperti; Adobe Flash, Autoplay, dan Lectora) dikategorikan baik. Kemampuan menggunakan hardware seperti; Komputer, Laptop, Smartphone, Printer, Scanner dan LCD proyektor juga dalam ketegori baik. Berdasarkan hasil analisis data di atas, diketahui rerata terendah terdapat pada item pernyataan nomor 8 dengan perolehan skor rerata 3,53, pernyataan "Saya mengetahui aplikasi untuk membuat media pembelajaran seperti; Adobe Flash, Autoplay, dan Lectora" dan diketahui rerata tertinggi terdapat pada item penyataan nomor 14 dengan perolehan skor rerata 4,73 "Saya dapat mengoperasikan aplikasi office seperti; Word, Excel, dan Powerpoint" sebanyak 44 responden menjawab sangat setuju (SS) dan sebanyak 16 responden menjawab setuju (S).

\section{SIMPULAN}

Technological Knowledge menjadi domain yang sangat penting bagi guru untuk meningkatkan kualifikasinya dalam upaya mempersiapkan diri sebagai tenaga pendidik yang terampil dan professional. Dari hasil penelitian dan pembahasan diatas dapat ditarik kesimpulan bahwa Kemampuan TK mahasiswa calon guru program studi PGSD FIP UM angkatan 2017 pada aspek pengetahuan teknologi dan penggunaan teknologi ditinjau dari tiap-tiap indikator tergolong dalam kategori baik. Sebagai seorang calon pendidik, mahasiswa calon guru diharapkan lebih mengeksplorasi lagi macam-macam teknologi dan memperkuat kemampuannya dalam menggunakan teknologi khususnya teknologi berbasis multimedia. Akan lebih baik juga apabila calon guru dapat mengembangkan sendiri media pembelajaran yang dipakai dalam kegiatan pembelajaran guna menunjang pembelajaran siswa, serta perlu mengasah kemampuannya dalam mengintegrasikan teknologi kedalam pembelajaran. Untuk penelitian selanjutnya dengan topik sejenis diharapkan agar dapat menggali lebih detail terkait setiap aspek yang diuji.

\section{DAFTAR RUJUKAN}

Arbianto, U. F., Widiyanti, W., \& Nurhadi, D. (2019). Kesiapan Technological, Pedagogical And Content Knowledge (Tpack) Calon Guru Bidang Teknik di Universitas Negeri Malang. Jurnal Teknik Mesin dan Pembelajaran, 1(2).

Alavi, M., \& Gallupe, R. B. (2003). Using information technology in learning: Case studies in business and management education programs. Academy of Management Learning \& Education, 2(2), 139-153.

Arikunto, S. (2006). Metodelogi Penelitian. Yogyakarta: Bina Aksara.

Arikunto, S. (2011). Penilaian \& Penelitian Bidang Bimbingan dan Konseling. Yogyakarta: Aditya Media.

Candra, P. N., Soepriyanto, Y., \& Praherdhiono, H. (2020). Pedagogical Knowledge (PK) Guru Dalam Pengembangan dan Implementasi Rencana Pembelajaran. Jurnal Kajian Teknologi Pendidikan, 3(2), 166-177.

Chai, C. S., Koh, J. H. L., \& Tsai, C. C. (2013). A review of technological pedagogical content knowledge. Journal of Educational Technology \& Society, 16(2), 31-51.

Cox, S., \& Graham, C. R. (2009). Using an elaborated model of the TPACK framework to analyze and depict teacher knowledge. TechTrends, 53(5), 60-69.

Dhawati, D. A. A., \& Hariyatmi, H. (2017). Kemampuan Technological Knowledge (TK) Calon Guru Biologi FKIP UMS. Prosiding SNPBS (Seminar Nasional Pendidikan Biologi dan Saintek) Ke2. 
Fuada, Z., Soepriyanto, Y., \& Susilaningsih, S. (2020). Analisis Kemampuan Technological Content Knowledge (TCK) Pada Mahasiswa Program Studi Pendidikan Guru Sekolah Dasar. Jurnal Kajian Teknologi Pendidikan, 3(3), 251-261.

Hewitt, J. (2008). Reviewing the handbook of technological pedagogical content knowledge (TPCK) for educators. Canadian Journal of Science, Mathematics, and Technology Education, 8(4), 355360 .

Hidayati, N., Setyosari, P., \& Soepriyanto, Y. (2019). Kompetensi Technological Pedagogical Content Knowledge (TPACK) Guru SOSHUM Setingkat SMA. Jurnal Kajian Teknologi Pendidikan, 1(4), 291-298.

Ibda, H., \& Rahmadi, E. (2018). Penguatan literasi baru pada guru madrasah ibtidaiyah dalam menjawab tantangan era revolusi industri 4.0. JRTIE: Journal of Research and Thought of Islamic Education, 1(1), 1-21.

Jordan, K. (2012). Beginning teacher TPACK knowledge: Influence of school type. ACEC2012: ITs Time Conference. In Proceedings of the 2012 Australian Computers in Education Conference.

Lestari, S. (2016). Analisis kemampuan technological pedagogical content knowledge (TPACK) pada guru biologi SMA dalam materi sistem saraf. In Proceeding Biology Education Conference: Biology, Science, Enviromental, and Learning (Vol. 12, No. 1, pp. 557-564).

Listiawan, T., \& Baskoro, W. W. (2015). Analisis Technological Content Knowledge (TCK) calon guru matematika dalam menggunakan perangkat lunak geometri dinamis. In Prosiding Seminar Nasional Matematika Dan Pendidikan Matematika UNY (pp. 827-834).

Tammy, R. J., \& Heflebower, M. (2012). Teaching \& Assessing 21 st Century Skills. The Classroom Strategies Series.

Mishra, P., \& Koehler, M. J. (2006). Technological pedagogical content knowledge: A framework for teacher knowledge. Teachers college record, 108(6), 1017-1054.

Nasution, S. H. (2018). Pentingnya literasi teknologi bagi mahasiswa calon guru matematika. Jurnal Kajian Pembelajaran Matematika, 2(1), 14-18.

RI (Republik Indonesia). (2005). Undang Undang Nomor 14 Tahun 2005 tentang Guru dan Dosen. Jakarta.

RI (Republik Indonesia). (2015). Permendikbud Nomor 23 Tahun 2015 tentang Penumbuhan Budi Pekerti. Jakarta.

Rosyid, A. (2016, August). Technological pedagogical content knowledge: sebuah kerangka pengetahuan bagi guru Indonesia di era MEA. In Prosiding Seminar Nasional Inovasi Pendidikan.

Setyosari, P., Slamet, T. I., Ulfa, S., \& Oktaviani, H. I. (2019). Technology-Supported Learning Environment to Improve Higher-Order Thinking Experience of Social Science Teachers TPCK for the 21st Century Learning. ICLI 2018, 41.

Shulman, L. S. (1987). Shulman, Lee S.," Knowledge and Teaching: Foundations of the New Reform," Harvard Educational Review, 57 (February, 1987), 1-22.

Sintawati, M., \& Indriani, F. (2019, December). Pentingnya Technological Pedagogical Content Knowledge (TPACK) Guru Di Era Revolusi Industri 4.0. In Prosiding Seminar Nasional Pagelaran Pendidikan Dasar Nasional (PPDN) 2019 (Vol. 1, No. 1, pp. 417-422).

Sukmadinata. (2011). Metode Penelitian Pendidikan. Bandung: Rosdakarya.

Surahman, E., Sulthoni, S., Ulfa, S., Husna, A., Ramdiana, H., Thaariq, Z. Z. A., ... \& Qolbi, M. S. U. (2020). Pelatihan Micro Learning Object Berbasis TPACK bagi Guru-Guru SMA di Garut. Abdimas Pedagogi: Jurnal Ilmiah Pengabdian kepada Masyarakat, 3(1), 1-14.

Fadel, C., \& Trilling, B. (2010). 21st Century Skills: Learning for Life in Our Times. Education Review. 
Tjandrawinata, R. R. (2016). Industri 4.0: Revolusi industri abad ini dan pengaruhnya pada bidang kesehatan dan bioteknologi. Jurnal Medicinus, 29(1), 31-39. 